\title{
Ameliyat Sonrası Ağrıda Tamamlayıcı Terapiler
}

\section{Complementary Therapies in Postoperative Pain}

Nuriye Değirmeni, Sevgi Gürii, Nevin Kanan iii

'Dr.Öğr.Üyesi. Kütahya Sağlık Bilimleri Üniversitesi Sağlık Bilimleri Fakültesi Ebelik Bölümü, https://orcid.org/0000- 0002-7278-978X

iï̈ğr. Grv. Selçuk Üniversitesi Hemşirelik Fakültesi Cerrahi Hastalıkları Hemşireliği Bölümü, https://orcid.org/0000-0002-6925-3351

iiiProf. Dr. Haliç Üniversitesi Sağlık Bilimleri Fakültesi, Hemşirelik Bölümü, https://orcid.org/0000-0002-2852-2316

Öz

Binlerce yıllık tarihi bulunan tamamlayıcı uygulamaların, günümüzde ameliyat sonrası ağrısı olan bireylerde uygulanması artmıştır. Cerrahi hemşireliğinde bakımda ağrıya yönelik yeni yaklaşım ve girişimler tartışılmaktadır. Bunların arasında en günceli ise tamamlayııı terapilerdir. Bu konuda derleme, nicel, nitel ve randomize kontrollü çalışmalara ihtiyaç duyulmaktadır. Dünya Sağlık Örgütü, tamamlayıcı terapileri içeren geleneksel tıbbı; sağıı̆ın iyilik halinin sürdürülmesi ile birlikte fiziksel hastalıkların ve akıl hastalıklarının önlenmesi, tanısı, tedavisinde kullanılan farklı kültürlere özgü teori, inanç ve deneyime dayalı, izahı yapılabilen ya da yapılamayan bilgi, beceri ve uygulamaların bütünü olarak tanımlamaktadır. Tamamlayıcı uygulamaların yararlığı ve gerekliliği konusunda sağlık profesyonellerinin farklı görüşleri bulunmaktadır. Bir grup, bu uygulamaların tıbbi tedavi ve bakımda yeri olduğunu savunurken, başka bir grup ise tamamlayııı uygulamalar ve sonuçlarına ilişkin sorumluluk konularını tartışmaktadır. Günümüzde tamamlayıcı terapilerin kullanım nedenleri; hastaların modern tıp uygulamalarının yanında bu tedavi yöntemlerini umut olarak görmesi, tedavilerinin kontrolü kendi elinde tutma istekleri, toplumların kültürleriyle uyumlu ve kolay ulaşılabilir olması, daha az girişimsel işlem barındırması ve uygulayıcılarının hastaya daha fazla zaman ayırmasıdır. Bu derleme ile ameliyat sonrası ağıının önlenmesi, tedavisi ve bakımına yönelik tamamlayıcı uygulamalar incelenecektir.

Anahtar Kelimeler: Postoperatif ağrı, Tamamlayıcı terapiler, Hemşirelik

\section{ABSTRACT}

Complementary practices have thousands of years of history. The use of complementary practices in individuals with postoperative pain has increased today. New approaches and interventions for pain in surgical nursing are discussed. Complementary therapies are the most recent among them. There is a need for compilation, quantitative, qualitative and randomized controlled studies on this subject. World Health Organization traditional medicine including complementary therapies; It is defined as the whole of knowledge, skills and practices that can be explained or not, based on theory, belief and experience specific to different cultures, used in the prevention, diagnosis and treatment of physical diseases and mental illnesses, together with the maintenance of well-being. Health professionals have different views on the usefulness and necessity of complementary practices. One group argues that these practices have a place in medical treatment and care. Another group discusses complementary practices and responsibility for their consequences. The reasons for the use of complementary therapies today; Patients see these treatment methods as hope in addition to modern medical practices, their desire to keep control of their treatments, their compatibility with the cultures of the societies and their easy accessibility, less interventional procedures, and the practitioners' spending more time with the patient. In this review, complementary practices for the prevention, treatment and care of postoperative pain will be examined.

Key Words: Postoperative pain, Complementary therapies, Nursing

${ }^{*}$ Mersin Üniversitesi Tıp Fakültesi Lokman Hekim Tıp Tarihi ve Folklorik Tıp Dergisi, 2022; 12 (1): 55-66

DOI: 10.31020/mutftd.1018094

e-ISSN: 1309-8004, ISSN 1309-761X

Geliş Tarihi-Received: 02 Kasım 2021; Kabul Tarihi - Accepted: 20 Aralık 2021

iletişim - Correspondence Author: Nuriye Değirmen <nuriye.degirmen@ksbu.edu.tr> 


\section{Giriş}

Son yıllarda dünyada ve ülkemizde "Geleneksel ve Tamamlayıcı Tıp" (GETAT) uygulamaları kullanımında artış izlenmektedir. GETAT uygulamalarının yararlılığı ve gerekliliği konusunda sağlık profesyonellerinin farklı görüşleri bulunmaktadır. Bir grup, bu uygulamaların tıbbi tedavi ve bakımda yeri olduğunu savunurken, başka bir grup ise GETAT uygulamaları ve sonuçlarına ilişkin sorumluluk konularını tartışmaktadır. $^{1-3}$

Dünya Sağlık Örgütü (DSÖ) geleneksel tıbbı; sağlığın iyilik halinin sürdürülmesi ile birlikte fiziksel hastalıkların ve akıl hastalıklarının önlenmesi, tanısı, tedavisinde kullanılan farklı kültürlere özgü teori, inanç ve deneyime dayalı, izahı yapılabilen ya da yapılamayan bilgi, beceri ve uygulamaların bütünü olarak tanımlamaktadır. Tamamlayıc tıp, bir ülkenin kendi geleneklerinin parçası olmayan ve sağlık sistemine tam olarak dahil olmamış uygulamalardır. Aynı zamanda konvansiyonel tıbbın destekleyicisi olarak tanımlanmıştır. "Geleneksel tıp” ve "tamamlayıcı tıp” terimleri birbirinin yerine de kullanılmaktadır. ${ }^{2}$

Günümüzde GETAT'ın kullanım nedenleri; hastaların modern tıp uygulamalarının yanında bu tedavi yöntemlerini umut olarak görmesi, tedavilerinin kontrolü kendi elinde tutma istekleri, toplumların kültürleriyle uyumlu ve kolay ulaşılabilir olması, daha az girişimsel işlem barındırması, GETAT uygulayıcılarının hastaya daha fazla zaman ayırmasıdır. Ülkelerin gelişmişlik düzeylerine göre kullanım nedenleri farklılık göstermekle birlikte, gelişmekte olan ülkelerde GETAT toplumun temel sağlık ihtiyaçlarını karşılamak için, gelişmiş ülkelerde ise konvansiyonel tıbbın çare bulamadığı hastalıklar için kullanılmaktadır. ${ }^{4-5}$

GETAT kapsamında içerikleri ülkeler arasında farklılık gösteren çeşitli uygulamalar, bitkisel ürünler ve uygulayıcılar bulunmaktadır. Ülkemizde 27.10.2014 tarihi ve 29158 sayılı Resmî Gazetede, 15 yöntem ve uygulamayı içeren "Geleneksel ve Tamamlayıcı Tıp Uygulamaları Yönetmeliği" yayınlanmıştır. Bu yönetmelikte akupunktur, apiterapi, fitoterapi, hipnoz, sülük uygulaması, homeopati, kayropraktik, kupa uygulaması, larva uygulaması, mezoterapi, proloterapi, osteopati, ozon uygulaması, refleksoloji ve müzik terapi yöntemler yer almaktadır. ${ }^{6}$

Günümüzde hem halk hem de sağılk çalışanlarının GETAT uygulamalarına yoğun ilgi göstermesi ve yaygın olarak kullanmaya başlamaları yeni tartışmaların doğmasına neden olmuştur. GETAT uygulamaları ile ilgili olarak kimlerin, nasıl, nerede, hangi yöntemleri, hangi hastalara uygulayacağı ve yan etkileri tartışılmaktadır. ${ }^{2}$ Özel hasta gruplarında ve ameliyat sonrası kullanıma ilişkin sınırlı sayıda çalışma olması nedeniyle bu konuda çalışmaların yapılmasına gereksinim vardır. ${ }^{7}$

Cerrahi girişim geçirmesi planlanan bir hastanın fizyolojik ve psikolojik hazırlığında güncel gelişmeler takip etmeli ve kanıta dayalı hemşirelik uygulamaları doğrultusunda hemşirelik bakımı gerçekleştirilmelidir. Hastalarla etkili bir iletişim kurarak ve planlama yaparak hemşirelik bakımı uygulanmalı, kaydedilmeli ve gereğinde güncellenmelidir. Tüm bakım sürecinde hastanın rahatı ve güvenliği sağlanmalı, gizliliğine ve onuruna saygı gösterilmelidir. Günümüzde ameliyat sonrası ağrı tüm bireylerde görülmekte ve bakımda ağrıya yönelik yeni yaklaşım ve girişimler tartışılmaktadır. Bunların arasında en günceli ise tamamlayıcı tedavilerdir. Bu konuda nicel, nitel ve randomize kontrollü çalışmalara ihtiyaç duyulmaktadır. ${ }^{8}$

Bu derleme ile ameliyat sonrası ağrının önlenmesi ve tedavisine yönelik GETAT uygulamalarının cerrahi hemşireliğinde kullanım durumu incelenecektir.

\section{Ameliyat ve Ağrı}

Ameliyat sonrası ağrı, cerrahi girişimin yol açtığı travma ile nosiseptör uyarılmasının sonucu başlayan ve çoğunlukla birkaç gün içerisinde azalan akut ağrıdır. Son yıllarda ameliyat sonrası ağrının fizyopatolojisinin 
daha bilinir hale gelmesi ve ağrı yönetimine ilişkin farklı uygulamalar kullanılmasına rağmen literatürde ameliyat sonrası ağı yönetiminin etkili yapılamadığı ve bu sebeple hastaların yaklaşık yarıdan fazlasının orta düzey üstünde ağrı yaşadığı bildirilmiştir. ${ }^{9}$ Literatürde ameliyat sonrası ağrı yönetiminin yetersiz olmasının, iyileşmenin gecikmesine, hastanede yatış süresinin uzamasına ve maliyetlerin artmasına neden olduğu belirtilmektedir. Akut ağrının fizyolojik, psikolojik ve sosyal yönü bulunmakta olup, bütüncül bakım uygulamaları ile ağrı giderilebilmektedir. Ağrı yaşayan bireylerde anksiyete, huzursuzluk, yorgunluk, halsizlik, rol performansında düşme, sempatik aktivitede artma, uykusuzluk, iştahsızlık, korku ve iletişim sorunları vb. problemler görülmektedir. Ayrıca yaşam bulgularında olumsuz değişimlere, yaşam kalitesinin azalmasına ve akut ağrının kronik ağrıya dönüşmesine neden olabilmektedir. ${ }^{9}$

Türkiye'de 2019 yılında cerrahi hemşirelerinin tamamlayıcı ve alternatif yöntemlere ilişkin bilgi düzeylerini belirlemek amacıyla yapılan bir araştırmada, hemşirelerin en çok soğuk uygulama (\%78), sıcak uygulama (\%73.2), masaj (\%54.3), spiritüel tedavi (\%40.2) ve bitkisel tedavi (\%39) yöntemlerini bildikleri; ameliyat sonrası ise soğuk uygulama (\%40.2), sıcak uygulama (\%34.1), bitkisel tedavi (\%27.4), masaj (\%22.6) ve spiritüel tedaviyi (\%15.2) kullandıkları bildirilmiştir. Çalışma sonunda, cerrahi hemşirelerinin tamamlayıcı ve alternatif yöntemler hakkında bilgilerinin istendik düzeyde olmadığı ve ameliyat sonrası hastalarda görülen semptomlar için tamamlayıcı ve alternatif yöntemleri yeterince uygulamadıkları belirtmiştir. ${ }^{10}$

Literatürde, ameliyat sonrası ağrıyı hafifletmek amacıyla genellikle farmakolojik (analjezik) yöntemlerin etkinliği değerlendirilmiştir. Analjezikler, ameliyat sonrası ağrının yönetiminde vazgeçilmez olmakla birlikte her zaman hastanın ağrısının yeterli düzeyde hafiflemesini sağlamayabilir. Ayrıca, analjeziklerin istenmeyen bazı yan etkileri vardır. Bu nedenle hemşirelerin hastaların ameliyat sonrası yaşadığı ağrıyı hafifletmek için farmakolojik yöntemlere ek olarak farmakolojik olmayan yöntemleri kullanmalarının, farmakolojik yöntemlerin etkinliğini arttırdığı bildirilmektedir. ${ }^{9}$ Ağrı yönetiminde etkili olarak kullanılabilen dikkati başka yöne çekme, relaksasyon, terapotik dokunma, TENS (transkutanöz sinir uyarımı), bilgi verme, psikolojik destek, hipnoterapi, akupunktur, müzik terapi, masaj ve aromoterapi gibi birçok farmakolojik olmayan yöntem bulunmakla birlikte, bu yöntemlerin ağrı üzerindeki etkisi ile çalışmaların kanıt düzeyi düşük olduğu bildirilmektedir. Çalışmalarda hemşirelerin farmakolojik olmayan yöntemleri uygulamadıkları, ağrının giderilmesinde çoğunlukla analjezik verdikleri ve hemşirelik kayıtlarında da verdikleri analjezik ilacın adı ve dozunun yer aldığı gösterilmiştir..$^{8-10}$

Idwall ve Ehrenberg tarafından 2002 yılında İsveç'te yapılan bir araştırmada, ağrıya ilişkin hemşirelik kayıtlarını incelenmiş, sonuçta genellikle analjezik istendiği ve kayıtların yarıdan fazlasının analjezik etkisine yönelik olduğu belirtilmiştir. ${ }^{11}$

Hemşirelik eğitimi sürecinde ağrı yönetimi, farmakolojik ve farmakolojik olmayan yöntemlere ilişkin konular yer almasına rağmen hemşireler iş yaşamlarında ağrı yaşayan bireye yalnızca analjezik vermektedir. Bunun nedeni olarak araştırmacılar hastane ortamında kantitatif tıp modelinin hâkim olduğunu, bu modelin ağrının psiko-sosyal doğasını anlamak için uygun olmadığını belirtmektedir. ${ }^{12}$

Ağrı subjektif bir duygu olup yalnızca onu yaşayan birey tarafından tanımlanabilir. Bu nedenle hastanın yaşadığı ağrıyı ve rahatlatmak için yapılan uygulamaların yeterli olup olmadığını anlamanın en doğru yolunun bireylerin görüşlerini almaktır. Literatürde, ameliyat sonrası ağrıya ilişkin nicel çalışmalar yer alırken, nitel çalışmalar sınırlı sayıdadır. Oysaki nitel çalışmalar, hastanın ağrıyı nasıl algıladığı, yapılan uygulamaların etkinliğini değerlendirme ve hastanın beklentilerini açıklama konularına açıklık getirmesi bakımında önemlidir. ${ }^{8-12}$

Ameliyat sonrası ağrının değerlendirilmesi ve yönetimi cerrahi hemşirelik uygulamalarının ayrılmaz bir parçasıdır. Literatürde etkili ağrı yönetiminin bir hasta hakkı olduğu belirtilmekle birlikte uygulamada henüz 
hastaların ağrısının değerlendirilmesi ve yönetiminde var olan engellerin üstesinden gelinemediği ve engellerin zaman yönetimi, hasta ve hemşirelerin tutum ve inançlarından kaynaklandığı bildirilmektedir. Ayrıca, bu sorunun çözümü için hemşirelerin kendi uygulamalarını denetleme üzerine odaklanması gerektiği, bu şekilde uygulamada ağrı yönetimi ve bakım standartlarının artacağı ileri sürülmektedir. ${ }^{12}$

Literatürde ameliyat sonrası ağrının giderilmesi ile ilişkin uygulamaların istenilen düzeyde olmadığı, ameliyat sonrası ağrısı kontrol altına alınamayan hastaların hareket etme, soluk alıp verme ve öksürme aktivitelerini etkin yapamadığı bu nedenle de ameliyat sonrası komplikasyon gelişme riskinin yüksek olduğu vurgulanmaktadır. $^{8-12}$ Türkiye'de Yılmaz ve Güler'in 2011 yılında yaptıkları çalışmalarında, bireylerin ameliyat sonrası yaşadıkları ağrı nedeniyle, \%96.4'ünün öksürme, \%78.3'ünün hareket etme, \%53.6'sının uyuma ve \%46.7'sinin soluk almada zorlandığı belirtilmiştir. ${ }^{9}$ Hemşirelerin ameliyat sonrasında hastaların ağrı nedeni ile yaşadıkları sıkıntıları derin soluk alıp-verme, öksürme ve mobilizasyon sırasında yarayı destekleyerek ve hastaya yatakta uygun pozisyon vererek rahatlatma sorumlulukları vardır. ${ }^{12}$ Ancak, literatürde hemşirelerin çoğunluğunun ameliyat sonrasında ağrıya neden olan derin soluk alma, öksürme, mobilizasyon sırasında hastaları ve yarayı desteklemedikleri ile ağrıyı azaltacak uygun bir pozisyon alma konusunda yardım etmedikleri bildirilmiştir. ${ }^{8-12}$

Ağrı yönetim sürecinde "değerlendirme" önemli bir basamaktır. Yıllardır bilinmekle birlikte ağrının etkin olarak rahatlamasına yön verecek hemşirelik yaklaşımları hakkında deneysel bilgi ve uygulamaların sınırlı kaldığı bildirilmektedir. Bilindiği gibi ağrı yönetim sürecinde ağrının kişiye özgü yani öznel bir semptom olması nedeniyle hastanın tüm yönleri ile tanınması önemlidir. Bunun için hemşirenin doğru öykü alma, sürekli gözlem yapma ve uygun ağrı değerlendirme yöntemleri konusunda yeterli bilgiye sahip olması gerekmektedir. ${ }^{12}$

Türkiye'de Eti Aslan ve Badır’ın 2005'de hemşirelerin ağrı değerlendirmesi üzerine yaptıkları çalışmalarında hemşirelerin ağrının değerlendirilmesi ve hafifletilmesi ile ilgili bilgilerinin yetersiz olduğu bildirilmiştir. ${ }^{13}$

Suudi Arabistan'da 2008'de Eid ve Bucknall tarafından yapılmış bir çalışmada, hemşirelerin ağrıyı değerlendirme ve rahatlatmaya yönelik yaptıkları uygulamaların yetersiz olduğu belirtilmiş ve hemşirelerin nadiren ağrı ölçeği kullandıkları, ağrısı olan hastaya genellikle analjezik verdikleri, farmakolojik olmayan girişimleri uygulamadıkları ve ağrıya ilişkin kayıtlarının yetersiz olduğu belirtilmiştir. Aynı çalışmada bu sonuçların nedeni olarak; hemşirelerin ağrı değerlendirme araçlarına ile ilişkili yeterli bilgiye sahip olmadıkları, bir ölçek kullanarak ağrının değerlendirilmesinin gerekli olduğuna inanmadıkları, iş yükü fazlalığı ve denetim yetersizliği bildirilmektedir. Aynı çalışmada hemşirelerin bilgi ve inançlarının artırılarak ameliyat sonrası ağrı yönetiminde ilerleme sağlamak için hemşirelik eğitimi ve uygulamasında gerekli organizasyonların yapılması gerekmekte olduğu bildirilmiştir. ${ }^{14}$

YıImaz ve Güler 2011 yılında yaptıkları çalışmalarında, hastaların ameliyat sonrası yaşadıkları ağrıya yönelik hemşirelerin yalnızca analjezik ilaç uyguladıkları ve uygulamadan sonra hastanın ağrısının azalıp azalmadığını kontrol ettikleri ancak farmakolojik olmayan ağrı giderme yöntemlerini uygulamadıkları belirtilmiştir. ${ }^{9}$

Wang ve Keck tarafından Hindistan'da 2004 yılında yapılan bir çalışmada, ameliyat sonrası hastalara analjezik verilmesine rağmen hastaların hafif düzeyde ağrı yaşadığı, analjeziğe ek olarak masaj uygulanmasının analjezik sonrası hafif düzeyde yaşanan ağrı üzerinde etkili olduğu bildirilmiştir. ${ }^{15}$

Masajın etkili, ucuz, doğal ve ameliyat sonrası kolaylıkla uygulanabileceği bilinmektedir. Ameliyat sonrası dönemde hemşirelerin hastalara uyguladıkları müzik dinletme, soğuk uygulama, masaj ve gevşeme egzersizleri gibi uygulamaların hastaların ağrı düzeyini azalttı̆̆ı ve rahatlamalarına neden olduğu belirtilmektedir. ${ }^{9,10,12}$ 
Hemşirelik eğitimi sürecinde ağrı kavramı, ağrı ölçekleri ve ağrının yönetiminde farmakolojik ve farmakolojik olmayan yöntemlerinin kullanımı öğretilmekte ve bu bilgiler klinik uygulamalar sırasında hastalar üzerinde pekiştirilmektedir. ${ }^{12}$ Hemşirelerin çalışma yaşantılarında okulda öğrendikleri bilgileri değil klinikte var olan uygulamaları benimsemelerinden dolayı daha çok analjezik ilaç uygulamayı tercih ettikleri bildirilmiştir. ${ }^{9,10}$

Hastalara ameliyat sonrası yaşayacağı ağrı ve ağrı yönetimi ile ilişkin verilen bilgilerin ağrıyı azalttığı bilinmektedir. ${ }^{9-12}$ Bu konuda Dihle, Bjolseth ve Helseth tarafından Norveç'te 2006 yılında yapılan bir çalışmada hemşirelerin hastalara ağrı konusunda bilgi vermedikleri bildirilmektedir. ${ }^{16}$

Ameliyat sonrası ağrıda, ameliyat türü ve ameliyat bölgesi etkilidir. Abdominal alan, yoğun sinir ağı ve diyafragmaya yakın olması nedeniyle en şiddetli ağrının yaşandığı ameliyat bölgesidir. Şiddetli ağrı nedeniyle hasta, derin solunum/öksürük egzersizleri, mobilizasyon ve uyku gibi iyileşme sürecini hızlandıracak aktiviteleri yapamaz ve ameliyat sonrası komplikasyon gelişebilir. ${ }^{12}$ Hastalardan bir kısmı mobilizasyon sırasında ağrı yaşamaktadır. Abdominal cerrahide hastaların ağrı ve anksiyetesini azaltmaya yönelik yapılan, sistematik relaksasyon eğitiminin ağrı düzeyini azalttığı ve hastaların daha erken mobilize oldukları ve daha kısa süre hastane de yattıkları belirtilmiştir. Yan etkisinin bulunmaması nedeniyle farmakolojik olmayan yöntemlerin analjeziklere ilave olarak kullanılmasının önemli olduğu vurgulamıştır. ${ }^{8-}$ $10,12,13,15$

\section{Ameliyat Sonrası Ağrıda Geleneksel ve Tamamlayıcı Terapiler}

\section{Ameliyat Sonrası Ağrıda Akupunktur}

Akupunktur, geleneksel Çin Tıbbına dair bir bakım yöntemi olup, vücutta belli noktalarına iğne, lazer ışınları, elektrik stimülasyonu (elektriksel uyarı), kupa, kulak için tohum, iğne ya da manyetik topçuklar (bilyeler), termik stimülasyon (ISı uyarıII), akupres (masaj) ve ses/elektrik/manyetik titreşimler gibi uyarı yöntemleri ile vücuttaki bulunan özel noktaların uyarılması suretiyle yapılır. ${ }^{17,18}$

Geleneksel Çin Tıbbında hastada bozulmuş olan Yin-Yang dengesi, uygun akupunktur noktaları iğnelenerek yeniden sağlanır. Vücuttaki yaşam enerjisi (Qi enerjisi); 12 meridyen (ana kanal), 8 ekstra meridyen (ilave kanal) ve bu meridyenlerin kollateralleri (yan kanalları) olarak bilinen enerji kanallarında dolaşmaktadır (akmaktadır). Bu kanallar boyunca, belli yerlerde özel noktalar bulunmaktadır. ${ }^{17}$

Vücut akupunkturu olarak bilinen makro sistem akupunkturunda, vücudun tümüne dağılmış akupunktur noktalarına uygulama yapııır. Mikro sistem akupunkturunda ise, vücudun tüm organ ve parçalarına karşılık geldiği kabul edilen vücudun sınırlı ve iyi tanımlanmış bölgelerine (kulak, kafa derisi, ağız içi, el ve ayak gibi) işlem uygulanır. Kulak akupunkturu, mikrosistem akupunkturunda en yaygın olarak kullanılandır. ${ }^{19}$

Iğneli, moksa ve masaj akupunktur yöntemleri, akupunkturun geleneksel uygulamalarıdır. Elektro akupunktur, lazer akupunktur, manyetik akupunktur ve sono akupunktur yöntemleri ise akupunkturun modern uygulamalarıdır. ${ }^{18}$

Akupunktur ile ilgili literatürde ağrı, baş dönmesi, öksürük, nefes darlığı, çarpıntı, ishal, kabızlık, adet düzensizliklerinin tedavi edilebildiği yazmaktadır. Dünya Sağlık Örgütü’nün; tedavide akupunktur yöntemini tavsiye ettiği hastalıklar, solunum, sindirim, sinir ve kas-iskelet sistemi olmak üzere dört sistem içerisinde ele alınır. Amerika Birleşik Devletleri Ulusal Sağlık Enstitüleri (National Institutes of Health in the United States-NIH) tarafından düzenlen akupunktur ile ilgili "Konsensus Oluşturma Paneli"nde, hastalıkların tedavisinde akupunkturun etkili bir şekilde yardımcı olabildiği durumlarda tanımlanmıştır. ${ }^{20}$

Akupunktur, yan etkisi ve riski çok nadir olan güvenli bir tedavi yöntemidir. Ancak bazı durumlarda (kan hastalıkları, kanama-pıhtılaşma bozuklukları, tümör, epilepsi, kalp pili, stent, ve sürekli ilaç kullanımı gibi) hekime bildirilmesi gereklidir. İğne batırılan veya uyarı (elektrik gibi) verilen yerlerde, nadiren de olsa; 
kızarıklıklar, kabuklanmalar, küçük morarmalar, çok küçük kanamalar ve küçük şişlikler olabilmektedir. Bazı hastalarda tedavi sırasında ve sonrasında uyuklama ve hafif bir sersemlik hali ortaya çıkabilmektedir. Böyle durumlarda araç ile trafiğe çıkılmaması, konsantrasyonu etkileyecek işlerden kaçınılması önerilmektedir. ${ }^{20}$

Türkiye'de Erden ve arkadaşlarının 2015 yılında yaptıkları bir çalışmada akupunkturun laparoskopik kolesistektomi geçiren hastalarda ameliyat sonrası analjeziye etkisinin olup olmadığı araştırılmıs, araştırmada akupunktur ameliyat sonrası ağrı skorlarını azalttığı bulunmuş ancak ağrı kesici kullanımında farklılık saptanmamıştır. ${ }^{21}$

Akupunkturun ağrı tedavisinde kullanım yöntemleri, hasta profili konuları ve etkisi hala tartışmalıdır ve ileri çalışmalara ihtiyaç vardır. Akupunkturun ameliyat sonrası akut ağrılarda kullanıldığı belirtilmektedir. ${ }^{22}$

\section{Ameliyat Sonrası Ağrı Kontrolünde Müzik Terapi}

Ruh haline uygun bir müzik dinlenildiğinde fark etmeden müziğe ayak uydurulur. Ayak uydurma, dinlenilen müziğe göre beyin dalgalarının, kalp ritminin, nefes alıp vermenin, duygusal gücün, zamanlamanın, hızın ve diğer organik ritimlerin nasıl değiştiğini açıklar. Müzik iyileşme sürecinde güçlü bir hızlandırıcı görevi üstlenir. Bedeni, her birinin benzersiz sanatsal yeteneği ve akort edilme şekli olan çok hassas bir enstrümanlar topluluğuna benzetmek yerinde olur. ${ }^{23}$

Müziğin en bariz iyileştirici kullanımı stresi azaltmaya ve gevşemeye yöneliktir. ${ }^{23}$ Bunun dışında müziğin ağrı, stres, kalp hastalıkları, kireçlenme ve amfizem üzerinde de etkili olduğu bildirilmiştir. ${ }^{23}$

Müzik, özellikle ağıı çeken insanlar için, sessizlikten daha iyidir, çünkü sessizlik rahatsızlığın daha çok bilincinde olmaya neden olur. Ağrı kontrolünde müzik terapi uygulamasındaki amaç; dikkati ağrıdan ya da rahatsızıktan başka bir yöne çekmektir. Yani "dikkat dağıtmak" tır ki bu sayede ağrı hissedilmesi azalabilir. ${ }^{23}$

Müzik terapi, onkoloji ve terminal dönem hastalarında, kaygıya neden olabilecek herhangi bir tıbbi ve cerrahi prosedürden önce, süresince ve sonrasında, doğumhanelerde, yoğun bakım ünitelerinde (kardiyak bakım, yeni doğan bakım üniteleri gibi), ana-çocuk sağlığı alanlarında (pediatri, doğumhane, kadın hastalıkları, kreş gibi) ve ameliyathaneler gibi birçok alanda kullanılmaktadır. ${ }^{23}$

Müzik terapi kapsamında yer alan uygulamalar şunlardır:

- Ana ses şifacılığı usulleri

- Mantra Söyleme

- Tonlama

- Yankılanan Frekans Tedavisi

- Sonik Bindirme Teknolojisi

- İ̧itsel Zenginleştirme Teknolojisi

- Ses Analizi Terapisi

- Vibro Akustik Terapi

- Diyapazon Terapisi

- Sono Punktur

- Doğal Akustik Enstrümanlar

- Kompakt Diskler 
- (CD) Müzik Terapi. ${ }^{23-25}$

Türkiye'de Avşar, Özlü ve İnce tarafından 2016 yılında; müzik terapinin kolesistektomi olan hastaların ağrıları üstünde etkisini belirlemek amacı ile kontrol gruplu yarı deneysel olarak yapılmış bir çalışma sonucunda, müzik terapinin maliyet açısından ekonomik, kolay ve ağrının giderilmesinde olumlu etkileri ile ameliyat sonrası kliniklerde uygulanmasının hastaların ağrı algısını giderebileceği belirtilmiştir. Laparoskopik kolesistektomi ameliyatı geçiren 60 hasta üzerinde çalışıımış, deney grubundaki hastalara hastanedeki rutin uygulamaların yanı sıra harici kulaklık ile 30 dakikalık "Hüseyni" makamında müzik dinletilmiş, kontrol grubundaki hastalara ise hastanedeki rutin uygulamalar dışında herhangi bir girişim yapılmamıştır. Deney ve kontrol gruplarında Sözel Tanımlayıcı Skala (STS) ve Görsel Analog Skalası (GAS) ile ağıı puan ortalamaları belirlenmiştir. Deney grubundaki hastaların büyük çoğunluğu (\%80.0) girişim sonrası ağrısının olmadığını veya hafif düzeyde ağrısı olduğu ifade ederken, kontrol grubundaki hastaların büyük çoğunluğu (\%53.3) orta/şiddetli ağıı tanımlamıştır. Ayrıca deney grubundaki hastaların GAS $(4.53 \pm 1.6)$ puan ortalamalarına göre anlamlı düzeyde daha düşük olduğu bulunmuştur. Maliyet açısından ucuz ve uygulanmasının kolay olması ile ağrıyı azaltmadaki olumlu etkileri nedeniyle ameliyat sonrası hastalara müzik terapi uygulamasının hastaların ağrı algısını azaltacağı bildirilmiştir. ${ }^{24}$

Ameliyathane için en uygun müzik kaygıyı azaltmak için tasarlanmış olan anksiyolitik müziklerdir. Müzik terapistiyle beraber seçilen müziklerin hastaya ameliyat öncesi, sırası ve sonrasında kulaklıkla dinletilmesi önerilmektedir. ${ }^{24,25}$

Poulsen ve Coto tarafından Hindistand'a 2017 yılında yazılan bir sistematik derlemede, ameliyat sonrası ağrıda müzik terapisi ile ilgili yapılan çalışmalar incelenmiş, sonuçta; ameliyat sonrası ağrıda müzik terapisinin hemşirelik uygulamaları arasında kullanılmasını tavsiye etmişler ve etkili bir yöntem olduğunu bildirmişlerdir. ${ }^{25}$

\section{Ameliyat Sonrası Ağrıda Aromaterapi}

Aromaterapi; "Tamamen bitkilerden elde edilen yağların kullanımı", "Terapötik uçucu yağların inhalasyon yoluyla koklanarak ya da diğer yollarla iyileştirmesi" ve "Bitkilerden elde edilen uçucu yağların masaj, friksiyon, inhalasyon, kompres ve banyo yoluyla uygulanarak doğal tedavi sağlaması" gibi farklı şekillerde tanımlanmaktadır. ${ }^{26}$ Bitkilerle tedavi anlamına gelen fitoterapinin bir dalıdır. Fitoterapide tıbbi amaçlarla bitkinin bir bölümü ya da tamamı kullanılırken, aromaterapi de sadece distilasyon (damıtma) ve sıkma yöntemleriyle elde edilen esansiyel yağları kullanılmaktadır. ${ }^{27}$

Esansiyel yağların içindeki bileşenlerin emilebilmesi için dört temel yol vardır. Bunlar;

1. Topikal yol: Dokunma, kompres ya da banyo yoluyla derinin kullanılması,

2. Dâhili yol: Gargara, vajinal ya da anal fitil yoluyla mukozanın kullanılması,

3. Ağız yolu: Jelatin kapsüller ile ya da bal, alkol veya seyreltici içinde sulandırma yoluyla uygulama,

4. İnhalasyon yolu: Doğrudan ya da dolaylı olarak, buharla ya da buharsız olarak soluma yoluyla uygulamadır. ${ }^{28}$

Aromaterapi uygulamalarında dikkat edilmesi gereken kurallar uygulama yoluna göre değişmekle birlikte, genel olarak bazı kurallara uymak gerekmektedir. Bunlardan başlıcaları şunlardır: ${ }^{26}$

$\checkmark$ Saf esans yağlarını satın alırken dikkatli olunmalıdır.

$\checkmark$ Yağları az miktarda satın almak daha uygundur.

$\checkmark$ Yağlar koyu renkli cam şişelerde ve güneş görmeyen yerde saklanmalıdır. 
Uygulamayı damlalık aracılığıyla yapmak ölçü ve hijyen açısından daha uygundur.

Uygulama sırasında uçucu yağlar göze kaçırılmamalıdır.

$\checkmark$ Uygulama sırasında ısı kaynağı kullanılıyorsa yangın, sıcak su yanığı gibi tehlikelere karşı dikkatli olunmalıdır.

$\checkmark$ Masaj yapılırken uçucu yağ, taşıyıcı yağlarla seyreltilerek kullanılmalıdır.

$\checkmark$ Yağlar, uçucu oldukları için kullandıktan hemen sonra şişenin kapağı kapatılmalıdır.

$\checkmark$ Uygulamanın etkinliğini artırmak için yağın miktarını artırmak doğru bir girişim değildir. Önerilen dozda yağ kullanmak gerekir.

$\checkmark$ Seçilecek aromatik yağ tercihi konusunda bireylerin seçimleri dikkate alınmalıdır.

$\checkmark$ Gebelik döneminin özellikle ilk üç ayında kullanılabilecek esansiyel yağlar sınırlıdır.

Ayrıca, kullanılan yağın hangi bitkiden elde edildiği mutlaka sorgulanmalıdır. Örneğin; lavantanın bir çeşidi olan "lavandula angustifolia", gebelikte kontraendike değilken "lavandula stoechas", abortusa yol açabildiği için kontraendikedir.

Hemşirelerin aromaterapi uygulamalarında dikkat etmesi gereken altı alan bulunmaktadır:

a. En iyi uygulama yolunu tanımlamak,

b. Karışımın yoğunluğunu tanımlamak,

c. Masaj uygulamasında kullanılacak taşıyıcı yağı seçmek,

d. Aromaterapi uygulamasının sıklık ve süresini netleştirmek,

e. Hastanın değişime hazır ve motive olduğunu tanımlamak,

f. Sonuç kriterlerini ortaya koymaktır. ${ }^{26}$

Zimpel ve arkadaşları tarafından Brezilya'da 2020 yılında yapılan, sistematik bir gözden geçirme çalışmasında; sezaryen ameliyatı sonrası ağrının, annenin sağlığını olumsuz etkileyebileceği bildirilmiştir. Olumsuz etkilerle ilgili endişeler nedeniyle geleneksel ağrı giderici stratejilerin genellikle yeterince kullanılmamakta olduğu, tamamlayıcı alternatif terapilerin, ameliyat sonrası ağrı için bir alternatif sunabileceği, aromaterapi, aromaterapi ile birlikte analjezi, plasebo ile birlikte analjezi uygulaması ile karşılaştırıldığında 12 saatte ağrıyı azaltabileceği vurgulanmıştır. ${ }^{29}$

Ferruggiari ve arkadaşlarının 2012 yılında Amerika'da yaptıkları bir çalışmada, ameliyat sonrası kadınlarda nane esansı yağıyla yapılan aromaterapinin ağrı giderilmesinde anlamlı bir etkisinin olmadığı bildirilmiştir. ${ }^{30}$

Bikmoradi ve arkadaşlarının 2015 yılında İran'da yaptıkları bir çalışmada, koroner arter bypass greft sonrasında lavanta aromaterapisinin yaşam bulguları ve stres üzerinde etkisiz olduğu belirtilmiştir. ${ }^{31}$

\section{Ameliyat Sonrası Derin Solunum Egzersizleri}

Egzersiz; planlı, yapılandırılmış, istemli, fiziksel zindeliğin (fitness) bir ya da birkaç unsurunu geliştirmeyi amaçlayan fiziksel aktivite tipidir. Fiziksel zindeliğin sağlıkla ilgili bileşenleri; kardiyovasküler (aerobik) fitness, kas gücü ve dayanıklılığı, esneklik ve vücut kompozisyonudur. ${ }^{32}$

Hastaların ağrılarının azalması ve günlük yaşam aktivitelerini devam ettirmesini sağlayabilmek için kişiye özel hazırlanan egzersiz programları oluşturulabilir. ${ }^{33}$ 
Cerrahi için hastaneye yatırılan bireylerde, bakımın başarısı cerrahi tekniğe, bilgiye ve becerilere bağı olması kadar girişim öncesindeki hazırıklar ve sonrasındaki hemşirelik bakımıyla yakından ilişkilidir. Cerrahi işlem, anestezikler ve medikal tedavi, pulmoner fonksiyonları olumsuz etkiler ve sonrasında komplikasyonlara yol açabilir. Bunun sonucu olarak göğüs duvarında, batında insizyon; solunum kaslarının bütünlüğünün bozulmasına, girişim bölgesi ağrısına, frenik sinir baskılanmasına, diyafragma fonksiyonlarının bozukluğuna ve sistemik etkilere yol açarak solunumu azaltabilir. Böylece, hipoksi, akciğer kapasitesinde azalma, bronşlarda sekresyon artışı ve infeksiyonlar gibi sorunlara sebep olabilir. Cerrahi girişim öncesi bireye solunum egzersizlerini öğretme ve uygulatma, sonrasındaki solunum egzersizine devamın sağlanması komplikasyonları önleyebilir. ${ }^{34}$

Türkiye'de Yavuz ve arkadaşlarının 2015'de yaptıkları bir çalışmada, cerrahi öncesi solunum egzersizleri yapma oranı hastalarda \%17,5, sonrası solunum egzersizlerini yapma oranı $\% 97,5$ bulunmuştur. Ameliyat olacak hastalara solunum egzersizlerinin girişim öncesi öğretilme oranı ve hastaların bu uygulamayı yapması, sonrasına göre daha az bulunmuştur ve derin soluk alma egzersizlerini birinci gün hastaların $\% 92.5^{\prime}$ inin, ikinci gün \%80'inin yaptığı bulunmuştur. ${ }^{34}$

Ameliyat sonrası derin solunum egzersizleri içinde yer alan; diyafragmatik solunum egzersizleri hasta açısından yaşamsal önem taşıyan ve hastanın yaşam kalitesini olumlu yönde etkileyen önemli bakım uygulamalarından biridir. ${ }^{34}$ Hasta supine pozisyonda yatırılır. Rahat ve sakin soluk alıp vermesi söylenir. Sağ elimiz hastanın karnının üzerine, sol elimiz hastanın sternumunun üzerine yerleştirilir. Yavaşça burnundan nefes alması söylenir. İnspirasyon süresince hava akciğerlere doldukça sağ elimizin yukarı doğru yükselmesi gözlenir. ${ }^{33}$

Ameliyat sonrası hasta rahatının sağlanması için uygulatılabilecek derin solunum egzersizleri içinde yer alan büzük dudak solunumunda (pursed lip), hasta rahat bir pozisyonda oturtulur. Burnundan yavaşça nefes alıp, dudaklarını büzerek ıslık çalar gibi yavaş yavaş vermesi istenir. Egzersiz ayaktayken ve efor sarf ederken uygulatılır. ${ }^{33}$

Ülkemizde Kara ve arkadaşlarının 2013' de yaptıkları bir araştırmada, kronik obstrüktif akciğer hastalığının bakımı iyi yapılmaz ise cerrahi gibi komplikasyonlara sebep olabileceği belirtilmiş ve araştırmada bireylere uygulanılan pursed lip ve diyafragmatik solunum egzersizlerinin bireylerin göğüs ağrısı şiddetine ve solunum fonksiyonlarına olumlu etkisinin olduğu saptanmıştır. ${ }^{35}$

Ameliyat sonrası hasta rahatının sağlanması için uygulatılabilecek derin solunum egzersizleri içinde yer alan segmental solunum egzersizleri için hastaya rahat bir pozisyon verilir. Etkilenmiş akciğer bölgesi belirlenir. Ellerimiz belirlenen bölgenin üzerine yerleştirilir. Hastaya derin soluk alıp elimizi itmesi söylenir. Nefes aldığı sürece uygulanan basınç azaltııır. ${ }^{33}$

\section{Ameliyat Sonrası Ağrı Kontrolünde Aktif ve Pasif Eklem Hareket Açıklı (ROM) Egzersizleri}

Vücudun sagital, frontal ve transvers düzleminde eklemlerin maksimum seviyede hareket ettirilmesine eklem hareket açıklığı egzersizi denir. Aktif ya da pasif olabilir. Kasları kasılmasına göre 3 tipte olabilir. ${ }^{36}$

İzotonik Egzersiz: Kaslar kısalarak kasılır ve eklemler oynatılarak aktif hareket ortaya çıkar. Yürüme, koşma, yüzme gibi hareketler. ${ }^{36}$

İzometrik Egzersizler: Kaslar kasılmadan kısalır. Eklem hareket etmez. Kas hacmini, tonüsünü ve gücünü arttıran egzersizlerdir. ${ }^{36}$

İzokinetik Egzersizler: Kasların dirence karşı kasıldığı aktif egzersizlerdir. Direnç oluşturmak için özel araçlar kullanılır. Yaralanmalardan sonraki egzersizler. ${ }^{36}$ 
Aktif ve pasif, ROM egzersizlerinin faydaları: cerrahi sonrası sırt ve bel ağrısının azalmasını sağlar, yorgunluk, varis ve bacaklardaki ödemi azaltır, unutkanlık, stres, anskiyete, depresyon azalır, aşırı kilo alımı azalır, fazla kiloların verilmesinde yardımcı olur, LDL ve HDL kolesterol değerlerini düzenler. ${ }^{37}$

\section{Ameliyat Sonrası Ağrıda Refleksoloji}

Refleksoloji, endokrin bezler ve organlar ile bağlantısı olan eller, ayaklar ve kulaklardaki özel refleks noktalarına el ile uygulanan ve vücut işlevlerinin düzenlenmesine yardımcı olan bir teknik olarak tanımlanmaktadır. Vücuttaki her bir organ el, ayak ve kulakta belirli bir noktayı temsil etmektedir. Ayaklarda organların yansıdığı noktalar daha geniş bir alanda olduğu için bu noktalar el ve kulaktaki noktalara göre daha göre belirgin bir haldedir. Ayakların bir özelliği de vücudun hassas yerleri olmasıdır. Bu nedenle refleksoloji tedavisi için bu bölgede çalışmak daha etkili bir yöntemdir. Refleksoloji de ilgili noktaya basınç uygulanması durumunda elektrokimyasal sinir uyarıları aktive olur. Uyarı, sinir sisteminin uyarılması ile periferal sinir sistemi tarafından algılanır ve bir mesaj oluşur. Oluşan mesaj nöronlarla santral sinir sistemine iletilir. Efferent nöronlar ile spesifik organlara ve endokrin bezlere iletilir. Böylece mesaja cevap oluşturulur. Refleksoloji, inaktive olan bölgeyi uyarır ya da fazla aktive olan bölgeyi yatıştırır ve tüm vücut sistemini dengelemeyi hedefler. Refleksolojinin en fazla görülen yararlarından biri aşırı rahatlama sağlayıp bireyi gevşetmesidir. Düzenli seanslarla yapılan refleksoloji ile vücuttaki enerji tıkanıklıkları giderilerek vücuda dengeli bir biçimde enerji yayılmaya başlar. Bu sayede dolaşım problemleri ortadan kalkar, hücrelere oksijen daha kolay yayııır, lenf sistemi daha iyi çalışır ve vücuttaki toksinler daha kolay atılır. Baş, sırt, bel, kas migren ve kanser ağrılarında, kemoterapinin yan etkilerini hafifletmede, yaşam kalitesini arttırmada, sempatik ve parasempatik sinir sistemini ayarlamada, organ fonksiyonlarını düzenlemede, bağışıklık sistemini güçlendirmede, dolaşımı düzenlemede, infeksiyon süresini kısaltmada, stres, anksiyete, ajitasyon, gerginlik, depresyon, yorgunluk ve uykusuzluk durumlarında etkilidir. ${ }^{38}$

Ülkemizde Güven tarafından 2017 yılında yapılan bir çalışmada sezeryan sonrası ağrısının azaltılmasında refleksolojinin etkili olduğu bildirilmiştir. ${ }^{38}$

Purut'un 2018 yılında yaptığı çalışmada, kemoterapi alan cerrahi geçirmiş ve geçirmemiş akciğer kanseri hastalarında refleksolojinin uyku kalitesine ve bulantıya etkili olduğu, hastaların konforunu artırarak ağrı ve rahatsızlık hissetmedikleri bildirilmiştir. ${ }^{39}$

Bidgoli ve arkadaşlarının İran'da 2017 yılında yaptıkları bir çalışmada, koroner anjiyografi girişimi sonrası el refleksolojisinin anksiyeteyi düşürdüğü ve ağrı rahatsızlık hissini hafiflettiği bulunmuştur. ${ }^{40}$

\section{Sonuç}

Hemşire bilimcilerden Watson'a göre hemşirenin değişime önce kendisinden başlaması gerektiğini belirtilmektedir. ${ }^{41} \mathrm{Bu}$ da ancak hemşirenin varlığını anlamlandırması ve öz farkındalığını arttırması ile mümkündür. Bu durum hemşirenin terapötik olarak girişim uygulamasına fırsat sunacaktır. Hemşire öncelikle kendisi ve diğer meslektaşları için optimum iyileşme çevresini oluşturmalıdır. Bunun için hemşireler gevşeme egzersizleri, nefes egzersizleri, müzik terapi, taş, su ve renk terapilerini kullanabilirler. Watson oldukça soyut ve kompleks olan bakımın ancak bakım davranışları yoluyla somutlaştırılarak açığa çıkartılabileceğini ifade etmektedir. Insan Bakım Kuramında bakım bilinci kapsamında iyileştirici çevre yaratılması için şu bakım davranışlarının kullanıımasını önermektedir. Watson dokunma, otantik var olma, sanatsal dışavurumlar, günlük tutma, oyun-eğlence, mizah, doğaçlama, müzik, nefes egzersizleri/ hayal kurma/ imajinasyon, göz teması, gülümseme ve olumlu vücut hareketleri, aktif dinleme gibi uygulamalar önermiştir ${ }^{41}$ 
Ülkemizde Uzun ve Tan'ın 2004'de yaptığı çalışmalarında hemşirelerin \%64.5'i hemşirelik eğitimine ve \%62.3'ü klinik uygulamaya iyileştirici tamamlayıcı terapilerin entegre edilmesi gerektiğini ifade ettikleri bildirilmiştir. ${ }^{42}$

Halcon ve arkadaşlarının Amerika'da 2003'de yaptığı bir çalışmalarında hemşirelik öğretim elemanlarının \%95'inin iyileştirici bakım çevresi ve tamamlayıcı terapilerin klinik uygulamaya entegre edilmesini istediği saptanmıştır. ${ }^{43}$

Modern bakıma olan güvenin sağlanmasına katkı sağlamak ve hastaların zarar görmesi engellemek için hemşirelerin günlük pratiklerinde hastalara GETAT uygulamalarını kullanıp kullanmadığını yargılayıcı ve suçlayıcı olmayan bir ortam oluşturarak sorulmalı, GETAT uygulamalarının yararı, zararı, ilaç etkileşimleri, infeksiyon riskleri hakkında bilgi sahibi olunmalı ve bu bilgiler hasta ile paylaşılmalıdır. ${ }^{44}$

Geleneksel tamamlayıcı ve alternatif yöntemlerin kullanımı pek çok ülkede zamanla fazlalaşmaktadır. Bireylerin bu yöntemlerden yararlanma sebepleri arasında kültürle uyumluluk göstermesi, maliyet etkin olması, kolay ulaşılabilir olması, girişimsel işlem olmaması veya az olması olarak sıralanabilir. Ameliyat sonrası ağrının yönteminde bir umut olarak görülebilir.

Hemşirelerin konu ile ilgili eğitilmeleri, sertifikalandırılmaları, mevzuatlarda düzenleme yapılması, medyada konu ile ilgili farkındalık yaratılması ve kanıt düzeyi yüksek çalışmalar yapılarak kliniğe yansıtılması önerilebilir.

\section{Bilgi}

Çıkar çatışması yoktur.

\section{Araştırmacı katkı oranı beyanı}

Nuriye Değirmen: Fikir/kavram, tasarım, denetleme/danışmanlık, veri toplama ve işleme, analiz ve yorum, kaynak taraması, makalenin yazımı, eleştirel inceleme.

Sevgi Gür: Fikir/kavram, tasarım, denetleme/danışmanlık, veri toplama ve işleme, analiz ve yorum, kaynak taraması, makalenin yazımı, eleştirel inceleme.

Nevin Kanan: Fikir/kavram, tasarım, denetleme/danışmanlık, veri toplama ve işleme, analiz ve yorum, kaynak taraması, makalenin yazımı, eleştirel inceleme.

\section{Kaynaklar}

1. Yüksel NA, ve ark. Hekimlerin geleneksel ve tamamlayıcı tıp uygulamalarına bakış açısı. ESTÜDAM Halk Sağlı̆̆ı Dergisi 2019;4(3):276-286.

2. WHO Traditional Medicine Strategy 2014- 2023. WHO Library Cataloguing-in publication Data.

3. Öztürk H, Şaylıgil Ö. Geleneksel ve tamamlayıcı tıp uygulamaları yönetmeliği'nin etik açıdan değerlendirilmesi. Turkiye Klinikleri J Med Ethics 2016;24(1):1-10.

4. Ernst $\mathrm{E}$. The role of complementary and alternative medicine. BMJ 2000;321(7269):1133-1135.

5. Karahancı ON, ve ark. Geleneksel ve tamamlayıcı tıp uygulamaları yönetmeliği ile yönetmelik taslağı'nın karşılaştırılması. Türkiye Biyoetik Dergisi, 2015;2(2):117-26.

6. TC Resmi Gazete (2014) Geleneksel ve Tamamlayıcı Tıp Uygulamaları Yönetmeliği. 27 Ekim 2014. Sayı: 29158. Başbakanlık Basımevi. Ankara.

7. Barnes J. Quality, efficacy and safety of complementary medicines: fashions, facts and the future. Part II: Efficacy and safety. J Clin Pharmacol 2003;55:331-340.

8. Rızalar S. ve ark. Cerrahi hastalarının ameliyat öncesi ve sonrasında açlık ve susuzluk düzeylerinin incelenmesi. Sağılık ve Yaşam Bilimleri Dergisi 2019;1(2):32-36.

9. Yılmaz M, Gürler H. Hastaların ameliyat sonrası yaşadıkları ağrıya yönelik hemşirelik yaklaşımları: Hasta görüşleri. Ağrı 2011;23(2):71-79.

10. Uraz Ö. Cerrahi kliniklerde çalışan hemşirelerin ameliyat sonrası sık görülen semptomlara yönelik tamamlayıcı ve alternatif yöntemlere ilişkin bilgi ve uygulamaları. İnönü Üniversitesi Sağıı Bilimleri Enstitüsü Hemşirelik Anabilim Dalı Hemşirelik Yüksek Lisans Programı Tez Danışmanı: Günay U. Yüksek Lisans Tezi. 2019. 
11. Idvall E, Ehrenberg A. Nursing documentation of postoperative pain management. J Clin Nurs 2002;11(6):734-42.

12. Aksoy G, Kanan N, Akyolcu N. Cerrahi Hemşireliği Kitabı genişletilmiş 2 baskı. Nobel Tıp Kitabevleri. 2017. Bölüm 10: Çavdar i, Akyüz N. İstanbul. sy: 367-385.

13. Eti Aslan F, Badır E. Ağrı kontrolü gerçeği: Hemşirelerin ağrının doğası, değerlendirilmesi ve geçirilmesine ilişkin bilgi ve inançları. Ağrı 2005;17(2):47-51.

14. Eid T, Bucknall T. Documenting and implementing evidencebased postoperative pain management in older patients. Journal of Orthopeadic Nursing 2008;12:90-98.

15. Wang HL, Keck JF. Foot and hand massage as an intervention for postoperative pain. Pain Manag Nurs 2004;5(2):59-65.

16. Dihle A, Bjølseth $G$, Helseth S. The gap between saying and doing in postoperative pain management. J Clin Nurs 2006;15(4):469-79.

17. O'Connor J, Bensky D. Acupuncture: A Comprehensive Text. Washington: Eastland Press, 1981.

18. Biçer I, Balçık PY. Geleneksel ve tamamlayıcı tıp: türkiye ve seçilen ülkelerinin incelenmesi. Hacettepe Sağlık İdaresi Dergisi 2019;22(1):245-257.

19. Liu Z, Liu L. Essentials of Chinese Medicine. Vol 1, London: Springer-Verlag London Ltd, 2009.

20. Akçal F. Tanı ve tedavide akupunktur. Konya: Ebru Yayıncılık, 2004.

21. Erden $\mathrm{V}$, ve ark. Laparoskopik kolesistektomi operasyonlarında akupunktur uygulamasının ameliyat sonrası analjeziye etkisi. Ağrı 2015;27(3):155-159.

22. Sezen K. Akapunktur teorik ve pratik. İstanbul: Nobel Tıp Kitapevi; 2002.

23. Karamızrak. N, ses ve müziğin organları iyileştirici etkisi, Koşuyolu Heart Journal 2014;17(1):54-57.

24. Avşar G, Özlü ZK, İnce S. Müzikterapinin kolesistektomi olan hastaların ağrıları üzerine etkisi. Anadolu Hemşirelik ve Sağlık Bilimleri Dergisi 2016;19(2):100-105.

25. Poulsen MJ. Nursing music protocol and postoperative pain. Pain Management Nursing: Official Journal of the American Society of Pain Management Nurses 2017;19(2):1-10.

26. Buckle J. Aromatherapy in the context of nursing, The Nature of Aromatherapy. Clinical Aromatherapy in Nursing. 1st ed. London: Arnold Publisher; 1997. p.2-48.

27. Price S, Price L. How essential oils enter the body. Aromatherapy for Health Profes sionals. 2nd ed. New York: Churchill Living Stone; 1995.pp:7-91.

28. Başaran A. Natural aromatherapy: herbs\& essences. Turkiye Klinikleri J Med Sci 2009;29(5-1):86-94.

29. Zimpel SA, et al. Complementary and alternative therapies for post-caesarean pain. Cochrane Database Syst Review 2020;1(9):1-10.

30. Ferruggiari $L$, et al. The effect of aromatherapy on postoperative nausea in women undergoing surgical procedures. J Perianesth Nurs 2012;27(4):246-51.

31. Bikmoradi A, et al. Effect of inhalation aromatherapy with lavender essential oil on stress and vital signs in patients undergoing coronary artery bypass surgery: A single-blinded randomized clinical trial. Complement Ther Med 2015; 23(3):331-8.

32. Illkin E, et al. Menopozal kadınlarda egzersizin fizyolojik etkileri. Akdeniz Spor Bilimleri Dergisi 2020;3(2).

33. Erişkin İçin Kronik Hastalıklarda Fiziksel Aktivite Rehberi, Sağlık Bakanlığı, Ankara-2008.

34. Yavuz $M$, ve ark. Hastaların ameliyat öncesi ve sonrasında solunum egzersizlerini uygulama durumları. Ege Üniversitesi Hemşirelik Fakültesi Dergisi 2015;31(2):1-7.

35. Kara D, ve ark. Kronik obstrüktif akciğer hastalarına uygulanan pursed lip ve diyafragmatik solunum egzersizlerinin dispne şiddeti ve solunum fonksiyon testleri üzerine etkisi. Anadolu Hemşirelik ve Sağlık Bilimleri Dergisi 2013;16:4.

36. Ay Akça F. (Ed) Temel Hemşirelik, İstanbul: İstanbul Medikal. 2008.

37. Köken G, Yılmazer M. Gebelik ve egzersiz, Turkiye Klinikleri J Gynecol Obst 2007;17(5):385-92.

38. Güven EK. Elektif sezaryen olan hastalarda post-operatif ağrı ve anksiyetenin azaltılmasında refleksolojinin etkisi. Yüksek Lisans Tezi. 2017.

39. Purut HP. Kemoterapi Alan Akciğer Kanseri Hastalarında Ayak Refleksolojisi Uygulamasının Bulantı Kusma ve Uyku Kalitesine Etkisi. Doktora Tezi. 2018.

40. Bidgoli $\mathrm{M}$, et al. The effect of hand reflexology on anxiety in patients undergoing coronary angiography: A single-blind randomized controlled trial. / Complementary Therapies in Clinical Practice. 2017;27:31-36.

41. Boz İ, İyileştirici bakım çerçevesi, Balıkesir Sağlık Bilimleri Dergisi 2018;7(1):56-61.

42. Uzun O, Tan M. Nursing students' opinions and knowledge about complementary and alternative medicine therapies. Complement Ther Nurs Midwifery 2004;10:239-44.

43. Halcon LL, et al. Complementary therapies and healing practices: faculty/student beliefs and attitudes and the implications for nursing education. J Prof Nurs 2003;19:387-97.

44. Şahin S. Geleneksel, tamamlayıcı, alternatif tıp uygulamalarına genel bir bakış. Türk Aile Hek Derg 2017;21(4):159-162. 